\title{
Smart Retailing in COVID-19 World: Insights from Egypt
}

\section{Ismail Kotb}

Graduate School of Business, Arab Academy for Science, Technology \& Maritime Transport, Egypt

Riham Adel

College of Management \& Technology, Arab Academy for Science, Technology \& Maritime Transport, Egypt

\section{Abstract}

COVID-19 pandemic has had a significant impact on business in general and the retail sector in particular which was hardly hit as sales fell by 20 percent during this period. The main challenges that face retailers nowadays during COVID-19 outbreak include: balance in supply and demand; safety of employees; trust between retailer and consumer; distribution \& transportation capability; shortage of manpower and consumer behavior (Fernandes, 2020; Kumar et al., 2020; Pantano et al., 2020). Yet, retailers around the world started to understand the benefits and new opportunities offered by smart technologies (Inman and Nikolova, 2017; Renko and Druzijanic, 2014). New technologies like internet of things (IoT) can play a significant role in controlling the pandemic situation in the retail sector and are expected to bring substantial benefits such as lower labor costs, increased efficiency, attraction of new shoppers and the generation of new revenue channels (Roy et al., 2017; Vaishya et al., 2020; Wünderlich et al., 2013). However, only a limited number of retailers has adopted IoT due to the huge financial investments required and uncertainty of customers' acceptance (Alkemade and Suurs, 2012; Evans, 2011; Pantano et al., 2013). It is, thus, expected to see smart retailers taking a series of actions over the short to medium term to conserve cash and structure of their company for postCOVID-19 operations. This research aims to explore the retailers' perceptions towards the adoption of smart retail technologies in Egyptian retailing context throughout conducting a series of semi-structured interviews with mid-to-top level management in different retail organisations and discuss the advantages and challenges expected from smart retail technologies adoption. Moreover, the research explains how smart retail can help overcoming uncertainities and is considered a well managed response strategy by retailers to COVID-19.

Keywords: COVID-19, Egypt, Internet of Things (IoT), Smart Retail, Retail 4.0, OmniChannel 


\section{Introduction}

Technology development is ongoing with an exceptional speed (McLean and Wilson, 2019). One of the industries that is observing a revolution due to the continual advance in technology is the retail industry (Priporas et al., 2017). In this era, retailing has become a dynamic industry and consumers depending on technology have significantly increased (Zhitomirsky-Geffet and Blau, 2016).

Retailing has changed dramatically in the last decades, due to ongoing digitization that enabled increased innovation in retail sector. Retailing is promptly shifting from traditional in-store and multichannel practices to Omni-Channel practices (Ailawadi and Farris, 2017). Thus, the concept of retail 4.0 is about Omni-Channel retail experiences, breaking the boundaries between the physical and virtual, and integrating service experience of various channels through an innovative model.

The Omni-Channel business model includes the use of multichannels such as physical in-store locations, social media platforms, mobile web, mobile devices, mobile applications, Chabot's, and virtual reality and all of the channels can be leveraged to serve all of their customers in purchase process regardless where and when."OmniChannel retailing" is widely known as new age of retail (Verhoef et al., 2015). Therefore, one of the most critical and serious challenges for retailers today is how to integrate new digital technologies into traditional operations and services to deliver more advanced, tailored customer experiences regardless of the channel used by endcustomers.

While retailers usually lack modern capacity and they generally adapt to innovations; innovative and interactive technologies and systems for selling goods and services are available and growing fast to support customers and retailers (Pantano, 2014). Currently the Internet of Things (IoT) is considered as one of the highly rated technological and strategic innovations that are anticipated to create new business opportunities by 2020 (Fagerstrøm et al., 2020) throughout developing a digitally enhanced environment aiming to deliver intelligent and autonomous solutions for both service providers and customers. This linkage between physical and digital entities across virtual platforms is known as The Internet of Things (IoT) which is not a single technology, but it is more of a set of numerous complementary technologies with competencies to connect the virtual and physical world. IoT stands on three main principles: 1) identification 2) interaction and 3) communication. Taking into consideration that these pillars are not only applicable among themselves or with other associated objects, but also with end-users (Gigli and Koo, 2011; Hoffman and Novak, 2015; Miorandi et al., 2012; Roy et al., 2018). The retail industry is on the verge of introducing IoT and smart technology which will lead to a significant improvement in retailing processes as well as entertaining consumers (Dacko, 2017; Inman and Nikolova, 2017; Pantano et al., 2017; Roy et al., 2017; Willems et al., 2017).

The emergence of COVID-19 pandemic and its implications are causing negative 
impact in the short- and mid-term to retailers, therefore urgent strategies and tactics for retailers are required (Pantano et al., 2020). The integration of new and innovative technologies like Internet of Things (IoT) can play a key and major role in reducing retailers' problems in dealing with COVID-19 pandemic (Vaishya et al., 2020). This research aims at exploring the retailers' perceptions towards using smart technologies within the Egyptian retail context; consequently discuss the challenges resulting from smart retail technologies adoption as well as the advantages expected from shifting towards smart retail.

\section{Overview of Retail Business in Egypt}

Egypt retail market is one of the most appealing markets for investments in the world indeed. In addition, Egypt population is the biggest in the Middle East North Africa region (MENA). The population of Egypt as of January 2020 was 102,334,404 (Worldometer, 2020). Also, Egypt had one of most diversified economy in the Arab world. According to AT-Kearney (2016), Egypt is the third largest economy in the Arab world and its total retail sales amount to US\$ 133 billion. Egypt retail market is competitive, fragmented and traditional similar to many developing countries.

Overall, the retail industry in Egypt is mainly divided into two main sectors; modern and traditional retail. Mainly, traditional retail has served Egypt's consumers shopping needs for decades. The traditional retail sector includes several formats, such as street vendors, independent high-street shops, and neighborhood corner stores. Modern retail, also known as organized retail, refers to retailing activities achieved by licensed retailers who are registered for sales tax, income tax, and value added tax, etc. In recent years, Egypt retail market shifted from traditional retail towards modern trade. The modern retailing growth in recent years can be assessed by the rise of shopping malls, franchise stores along with the increasing number of grocery modern retail formats such as supermarkets, hypermarkets, and discounters. Inflation, complex bureaucracy, depreciation of the Egyptian pound versus dollar, terror attacks, and consumer spending power are the main challenges for retail investors in Egypt. However and despite these challenges, many local and multinational retailers have submitted plans to join or expand their business in Egypt.

Another exciting fact in Egypt's retail market is the rise of online retailing due to the evolution of smartphones and social media. Egypt has a number of key e-commerce platforms where "JUMIA", "SOUQ" and "NOON" are the most familiar ones. Also, there is a large segment of individuals initially starting up their businesses totally on online platforms, such as "Facebook", "Instagram" or other websites. According to ATKearney report (2016), online retailing business in Egypt has reached US\$ 544 million in $2015 / 2016$ which approximately forms $0.4 \%$ of the total retail sales amounted to US\$ 133 billion. Retail Experts suggest that online retailing activities volume will grow by $35 \%$ on annual basis. Applying this estimation and in case of constant demand on e-commerce products and services, online retailing volume is expected to become US $\$ 1.93$ billion by the year 2019/2020. 
Currently, COVID-19 pandemic caused significant negative implications in regards to national economies, businesses and individual jobs (Parker et al., 2020). According to The World Bank (2020), despite the extraordinary efforts of many governments to counter the decline with monetary policy support, it expects a 5.2 percent contraction in global GDP in 2020; this is considered the deepest global recession in decades. Since World War II, the world has not practiced such heavy restrictions on the freedom of individuals as those executed by numerous governments due to the COVID-19 pandemic (Pantano et al., 2020).

Service sectors such as retail hit hardly (Fernandes, 2020). Retail sales fell by 20 percent over the same period and COVID-19 pandemic has disrupted everything where huge challenges and uncertainties have impacted retail industry and the consumers' normal habits and behaviors in retail settings might be limited for now (Fernandes, 2020; Pantano et al., 2020)

Many consumers are in self-imposed isolation where trips to brick and mortar stores are no longer possible or fraught with challenges. Retail organizations around the world like Deloitte, KPMG, Nielsen, Forbes, IDC and McKinsey suggest that technology adoption can play a significant role in controlling the pandemic situations and retailers problems (Kumar et al., 2020; Vaishya et al., 2020).

For retailers, smart retail technology is expected to bring substantial benefits such as lowering labor costs, increasing operations' efficiency, attracting new shoppers and generating new revenue channels. In addition, it will provide consumers with tremendous benefits such as superior, convenient, entertaining, interacting, fast, satisfactory, personalized and smart shopping experience (Roy et al., 2017; Wünderlich et al., 2013).

\section{The Internet of Things (IoT) in Retailing}

The Internet of Things (IoT) also known as the Internet of Everything or the Industrial Internet is a novel technology standard seen as a worldwide network of machines and devices that are able to interact and connect with each other (Lee and Lee, 2015). Although the definition of IoT is still in its development stages, its generally agreed that "it is a paradigm where everyday things are embedded with technology that equips them with sensing, identifying, networking and processing capabilities which enable them to communicate with other devices and services over the Internet to accomplish objectives" (Whitmore et al., 2015). It is estimated that there will be between 25 billion and 50 billion connected devices by 2025. Furthermore, Manyika et al. (2015) predict that customers are expected to capture $90 \%$ of IoT benefits and it will have a potential impact of US $\$ 11$ trillion by 2025 . The IoT is considered as one of the most distinguished area of future technology and is attaining a huge attention from a broad range of industries. The real value of IoT for enterprises is attained when connected devices communicate and integrate with merchant systems, customer support systems, business intelligence applications, and business analytics. 
IoT is, therefore, recognized as the next big thing in the retail industry that is considered one of the most important areas for IoT applications (Gregory, 2015; Pantano and Timmermans, 2014) and it will have a significant impact on the retail industry namely in three crucial areas: (1) customer experience; (2) supply chain, and (3) new channels \& revenue streams (Firdausi, 2016; Gigli and Koo, 2011; Miorandi et al., 2012). The effective deployment of IoT in retail context could have an economic effect of $\$ 410$ billion to $\$ 1.2$ trillion per year in 2025. IoT Shelf Availability, Automated Checkout, Smart Customer Relationship Management and Real-time In-store Promotions are the most promising applications for IoT technology in the retail sector (Manyika et al., 2015).

In the new ecosystem, as more retail 4.0 technologies are adopted, it can be concluded that retailers of the future will rethink how to create and capture value in light of IoT technological advancement by introducing what so called "SMART" store, products and services that are characterized with hybridization between new technologies and traditional retail features to engage with their customers and create seamless shopping experiences embedded in our daily life activities.

Therefore, it is argued that IoT enabled technologies will be a game changer for retail sector in the future. IoT technologies help creating interactive consumer experiences giving rise to "smart" retail stores where inventories levels and customer movement in store can be tracked; real-time notifications when products are out of stock to restock; install smart shelves; alert consumers about promotions and discounts when near certain products and automated checkouts. Therefore, the paper main objective is to explore the perceptions of Egyptian retailers towards the adoption of smart technologies and examine the main constraints and benefits of smart retail adoption within the Egyptian context. To achieve this objective the researcher will attempt to answer the following questions:

Q1. What are the challenges and obstacles of smart retail adoption?

Q2. What are the advantages and expected results of smart retail adoption?

Q3. What are the retailers' recommendations for successful smart retail adoption?

\section{Methodology}

A qualitative research method has been selected for this research. Qualitative data analysis procedures are considered to be very useful and necessary because the baseline knowledge on smart retail, IoT technology and the surrounding issues with respect to the population of interest are still new.

The most widely used method for sorting out sample size for qualitative interviews is the saturation of information (Vasileiou et al., 2018). In other words, sample size for qualitative research determine, when no new information, no new data and no new themes can be extract from participants (Morse, 1995). Moreover, Morse (1995) affirms that the more useable data are collected from each participant, the fewer 
participants are needed. Furthermore, he confirmed that in qualitative interviewing parameters such as the scope of study, the nature of topic (i.e. complexity, accessibility), the quality of data, experts experience aim and the study design should be taken into account by researchers to determine the qualitative research sample size.

A semi-structured interview consisting of 9 questions (See Appendix A) is designed in relation with the research objective; however, the discussions remain flexible and open-ended and the participants are informed that their honest and frank opinions are what the researcher is interested in and that there is not a wrong or right answer.

The interviews mainly focused on getting insights from the retail managers concerning: (1) the impact of COVID-19 on the retail industry; (2) offline retailers readiness to implement smart retail technologies (SRT); (3) smart retail technologies (SRT) impact in physical stores; (4) the obstacles and challenges that affect the adoption of Smart Retail Technologies (SRT); (5) the advantages of smart retail technologies (SRT) adoption in retail sector; (6) their perception of post smart retail technologies (SRT) adoption results; (7) their perception towards consumers' willingness to adopt smart retail technologies (SRT); and finally (8) based on their experience in the retail industry, their recommendation to successfully adopt smart retail technologies (SRT).

Using a convenience sampling strategy to select the participants, five experts confirmed their willingness to participate in this study which was considered being sufficient for the purpose of the current study.

The participants are selected from different types of retail industry including: fashion, beauty and gifts retailing, food distribution, books and hypermarket chains. To assure the usefulness of the data, the researcher selected the participants with sufficient knowledge about smart technologies and its applications on retail sector. The interviews were conducted via ZOOM for approximately 45 minute per interview, and all interviews were audio recorded with the interviewee consent to increase the accuracy of data collected since it permits the interviewer to be more focused on the interviewee (Patton, 1990). It also allowed the researcher to transcribe each interview effectively. The researchers took handwritten notes during the sessions. After all the interviews were completed, the discussions were transcribed and data are organized in themes and analyzed. Table 1 illustrates the profile of each of the five cases that participated in the interview with brief information about the company, its size and if they currently adopt Smart Retail Technologies (SRT). 


\section{Table 1}

\section{The Sample Characteristics (Case profile)}

\begin{tabular}{|c|c|c|c|c|c|c|c|c|c|}
\hline $\begin{array}{l}\text { Case } \\
s\end{array}$ & Job title & $\begin{array}{l}\text { Manageme } \\
\text { nt Level }\end{array}$ & $\begin{array}{l}\text { Gende } \\
r\end{array}$ & $\begin{array}{l}\text { Locatio } \\
n\end{array}$ & $\begin{array}{l}\text { Experienc } \\
\text { e (years) }\end{array}$ & Company & Type & $\begin{array}{l}\text { Compan } \\
\text { y Size }\end{array}$ & $\begin{array}{l}\text { Type of } \\
\text { Technology } \\
\text { used/adopte } \\
d\end{array}$ \\
\hline $\begin{array}{l}R E- \\
01\end{array}$ & $\begin{array}{l}\text { Area } \\
\text { manager }\end{array}$ & Mid-level & Male & Egypt & $>10$ & \begin{tabular}{|l} 
ALEF \\
Bookstore \\
s
\end{tabular} & $\begin{array}{l}\text { Bookstore } \\
\text { Retailer }\end{array}$ & $>300$ & $\begin{array}{l}\text { Digital } \\
\text { platform }\end{array}$ \\
\hline $\begin{array}{l}R E- \\
02\end{array}$ & $\begin{array}{l}\text { Category } \\
\text { manager }\end{array}$ & Mid-level & Male & Egypt & $>15$ & $\begin{array}{l}\text { Carrefour } \\
\text { Egypt }\end{array}$ & $\begin{array}{l} \\
\text { Hypermarke } \\
t \& \\
\text { supermarke } \\
t \text { chain }\end{array}$ & $>6,000$ & $\begin{array}{l}\text { Digital } \\
\text { platform, } \\
\text { Self- } \\
\text { checkouts, } \\
\text { Click \& } \\
\text { collect, } \\
\text { Intelligent } \\
\text { self-service } \\
\text { kiosk }\end{array}$ \\
\hline $\begin{array}{l}R E- \\
03\end{array}$ & $\begin{array}{l}\text { Business } \\
\text { developme } \\
\text { nt manager }\end{array}$ & Mid-level & Male & Dubai & $>10$ & $\begin{array}{l}\text { Hershey } \\
\text { Company } \\
\text { Middle } \\
\text { East }\end{array}$ & $\begin{array}{l}\text { Chocolate } \\
\text { manufactur } \\
\text { er }\end{array}$ & $>40$ & $\begin{array}{l}\text { Digital } \\
\text { Platform }\end{array}$ \\
\hline $\begin{array}{l}R E- \\
04\end{array}$ & $\begin{array}{l}\text { Retail area } \\
\text { sales } \\
\text { manager }\end{array}$ & Mid-level & Male & Kuwait & $>20$ & $\begin{array}{l}\text { Chalhoub } \\
\text { Group } \\
\text { Middle } \\
\text { East }\end{array}$ & $\begin{array}{l}\text { Luxury } \\
\text { retailer in } \\
\text { beauty, } \\
\text { fashion, and } \\
\text { gift sectors. }\end{array}$ & $>12,000$ & $\begin{array}{l}\text { Digital } \\
\text { platform, } \\
\text { Smart } \\
\text { mirrors, click } \\
\text { \& collect, } \\
\text { Intelligent } \\
\text { self-service } \\
\text { kiosk }\end{array}$ \\
\hline $\begin{array}{l}\text { RE- } \\
05\end{array}$ & $\begin{array}{l}\text { Store } \\
\text { manager }\end{array}$ & Mid-level & Male & Egypt & $>10$ & Zara & $\begin{array}{l}\text { Fashion } \\
\text { retailer }\end{array}$ & $>1,000$ & $\begin{array}{l}\text { RFID } \\
\text { Readers, } \\
\text { Digital } \\
\text { platform, } \\
\text { Intelligent } \\
\text { self-service } \\
\text { kiosk }\end{array}$ \\
\hline
\end{tabular}

\section{Thematic Analysis}

When a pattern emerges repeatedly in multiple cases, it is identified as a theme, thus considered an explanatory finding that describes the phenomenon. The main purpose of this section is to develop a clear interpretation for the data collected and to distinguish between information relevant to all cases and those aspects that are exclusive to some cases in particular. First, data are decontextualized by exploring individual case, then data are re-contextualized by grouping into themes with 
commonalities taken from multiple respondents to reduce data across all cases (Ayres et al., 2003).

\section{Within Case Analysis}

The within-case analysis depicted the issues each expert reported in regard to the eight objectives mentioned above. Table 2 presents the eight objectives and relates each objective with the interview questions developed by the researcher.

\section{Table 2}

\section{Objectives and interview questions}

\begin{tabular}{|c|c|}
\hline Objectives & Question \\
\hline The impact of COVID-19 on the retail industry & $\begin{array}{c}\text { How is the current COVID- } \\
19 \text { pandemic affecting the } \\
\text { retail industry in Egypt? } \\
\text { To what extent SRTs could } \\
\text { help the retail industry } \\
\text { during the current pandemic } \\
\text { crisis? }\end{array}$ \\
\hline Offline Retailers readiness to implement SRT & $\begin{array}{l}\text { Which retailers have the } \\
\text { “capabilities necessary for } \\
\text { successful Smart Retail } \\
\text { Technologies } \\
\text { implementation? }\end{array}$ \\
\hline Smart retail technologies (SRT) impact in physical stores & $\begin{array}{c}\text { Which smart retail } \\
\text { technologies will have the } \\
\text { biggest impact if } \\
\text { implemented within retail } \\
\text { stores? Why? }\end{array}$ \\
\hline $\begin{array}{c}\text { Obstacles and challenges that affect the adoption of Smart } \\
\text { Retail Technologies (SRT) }\end{array}$ & $\begin{array}{l}\text { What are the obstacles and } \\
\text { challenges that may prevent } \\
\text { retailers from adopting } \\
\text { Smart Retail Technologies? }\end{array}$ \\
\hline $\begin{array}{c}\begin{array}{c}\text { Advantages of smart retail technologies (SRT) adoption in } \\
\text { retail sector }\end{array}\end{array}$ & $\begin{array}{l}\text { What are the changes and } \\
\text { expected benefits to take } \\
\text { place if retailers adopt smart } \\
\text { retail technologies? }\end{array}$ \\
\hline $\begin{array}{l}\text { Retail experts perception of post smart retail technologies } \\
\text { (SRT) adoption results }\end{array}$ & $\begin{array}{c}\text { What is your perception } \\
\text { regarding the changes smart } \\
\text { retail technologies may } \\
\text { create? }\end{array}$ \\
\hline $\begin{array}{l}\text { Retail experts perception of consumers' willingness to adopt } \\
\text { SRT }\end{array}$ & $\begin{array}{l}\text { Do you think the consumer } \\
\text { will accept using Smart } \\
\text { Retail Technologies? Why? }\end{array}$ \\
\hline
\end{tabular}




\begin{tabular}{c|c}
$\begin{array}{c}\text { Retail experts' acceptance to adopt smart retail technologies } \\
\text { (SRT). }\end{array}$ & $\begin{array}{c}\text { Are you considering/ } \\
\text { accepting adopting Smart } \\
\text { Retail Technologies? Why? }\end{array}$ \\
\hline
\end{tabular}

Case RE-01

First: concerning the impact of COVID-19 on the retail industry in Egypt, the respondent noted that with regards to online retailers who have been tested during this period, a few online retailers proved that they have the capacity to accept orders from new shoppers and to deliver a great online experience. He elaborated that the impact of COVID-19 on offline retailers in Egypt forced integration on online channel and moving for multichannel. Retailers recognise the necessity to merge all available channels including web store, mobile applications and social media and etc. Furthermore, the respondent stated that he expects to see further adoption of smart technology mainly in Egypt modern retail sector (e.g. shopping malls, supermarkets, hypermarkets, famous brands). He, finally, noted that the pandemic outbreak accelerated and forced the consumer adaptation to online shopping and it has become a habit. He also believes that many shoppers will continue to use the online platforms after the current situation ends.

Second: concerning retailers' readiness to implement SRT, he noted that he does not believe that Egypt offline retailers have the essential capabilities to implement SRT now.

Third: concerning the smart technologies, he believes it will have the most impact if implemented within physical stores (offline). Moreover, he confirms that the use of virtual mirrors instead of dressing rooms is expected to increase significantly; automated checkout and self-checkout payment system are very interesting technologies that can improve customer shopping experience. However, he mentioned that if systems do not work well or break easily, customers will avoid them and go to regular cashiers instead. $\mathrm{He}$ also added that he believes that these technological innovations are important, but automated technologies cannot replace humans totally, especially in developing countries.

Fourth: concerning the expected obstacles and challenges that may prevent retailers from implementing SRT, he noted that smart technologies require huge funding and financing investments. Moreover, he added that customers will be the biggest challenge, no matter how improvement smart technology can provide, without customer acceptance the technology would be useless.

Fifth: concerning the advantages of adopting SRTs in retailing, he noted that retailers can become more efficient, smart technology can prevent errors caused by human factors and reduce overall operation costs, response time to the minimum, improve the accuracy of inventory tracking, track goods across the supply chain, and help managers take better informed decisions with regard to lower prices either on promotional or low-turnover items, or increase pricing on higher-demand items and 
thus drive more sales and revenue.

Sixth: with regards to his perception of the changes smart retail technologies may create, he noted that he asserts that changes would be both positive and negative. As for the positive side, it can help retailers deal with COVID-19, generate new revenue stream and save retailers costs. As for the negative side, the automation would eliminate jobs and eventually it may affect Egypt's economy negatively.

Seventh: with regards to his perception on consumer willingness to accept and use SRTs, he noted that it mainly depends on consumers' age group; older generations would be a the major challenge for retailers while younger generations would accept and use smart technology and smart devices easily. Moreover, he mentioned that he believes younger generations would be the early adopters for smart retail technology and SRTs would enhance customer shopping experience in which shopping can be faster and enjoyable.

Eighth: with regards to his acceptance to SRT adoption in the future, he confirmed his agreement of the importance to shift towards smart retail and added that it can help retailers in the new post-COVID-19 world. and improve customers shopping experience.

\section{Case RE-02}

First: concerning the impact of COVID-19 on the retail industry in Egypt he noted that with regards to online retailers, online sales have increased in comparaison to last year. He elaborated that COVID-19's impact on offline retailers led to a drop on stores'sales, cash flow and forecasted profits for 2020. Further, the respondent stated that he expects the adoption of smart technology to increase in the coming years and offline retailer stores should deploy smart technologies to compete with online platforms. He, finally, noted that the pandemic accelerated the consumer adaptation to e-payment solutions.

Second: concerning retailers' readiness to implement SRT, he noted that he believes that multinational retailers only would have the financial and human resources capacity to implement smart retail technologies (SRT).

Third: concerning smart technologies, he believes to have the most impact if implemented within physical stores (offline). He believes that the use of real time in store promotions technology would help retailers increase their sales and improvetheir connection with target customer.

Fourth: concerning the expected obstacles and challenges that may prevent retailers from implementing SRTs, he noted that retail industry was hit by an economic slowdown, losses and decrease in revenue streams in 2020 due to COVID-19. He added that currently most retailers focus on cost savings and smart technologies, howeverthis would be costly to be fully implemented. Further, he noted that customers' willingness and trust to use smart technologies should be considered as 
the main challenge that can prevent retailers from smart technologies' adoption. Finally, he highlighted that the internet infrastructure in Egypt needs a huge investment to improve network connections and to ensure a high speed internet.

Fifth: concerning the advantages of adopting SRTs in retailing, he noted that retailers can become more efficient. Smart technology can reduce operations and labor costs, help offline retailers to compete with online stores, and improve shopping experiences for consumers. Thus drives more sales and revenue.

Sixth: with regards to his perception of the changes smart retail technologies may create, he noted that he is evident that changes would be positive. It will help retailers generate more revenues.

Seventh: with regards to his perception on consumer willingness to accept and use SRTs, he noted that consumers would use it by time especially if it is easy, useful, error free and saves customer time. Moreover, he mentioned that he believes smart technology would transform retail businesses; it would facilitate customers shopping, make it faster and enjoyable, and will help stores to interact and engage with customers better.

Eighth: finally with regards to his acceptance to SRT adoption in the future, he confirmed his agreement as long as it is easy, useful and convenient for consumers.

\section{Case RE-03}

First: concerning the impact of COVID-19 on the retail industry in Egypt, he claimed that e-commerce dominated the retail market during Corona virus pandemic. In his elaboration about the impact of COVID-19 on offline retailers, he noted that online sales grew, offline retailers'sales has shrunk and their market dominance was negatively impacted. He added that the pandemic accelerated the collapsing of the already struggling traditional retail sector. He pressured that it has become crucial to modern retail sector to use digital tools and platforms and to renovate and reshape their business models. Furthermore, the respondent stated that he believes that the pandemic would accelerate the use of smart technologies, but still it depends on the retailer's target customers acceptance. He, finally, noted that during the current pandemic, consumers' behavior and shopping preferences around the world have changed in which they were actively stockpiling emergency supplies (e.g. foodstuffs, canned goods, flour, sugar and bottled water) and reduced their spending on some other categories, such as apparel, footwear, accessories...etc.

Second: concerning retailers' readiness to implement SRT, he stated "only the multinational retailers in the modern retail sector can implement SRT, such as in Carrefour", he believes that small and local retailers may not be ready to implmenet SRT

Third: concerning the smart technologies, he believes it would have the most impact if implemented within physical stores (offline), he believes that automated checkout 
and self-checkout payment systems are the most realistic technologies that can be implemented currently in Egypt and the Middle East

Fourth: concerning the expected obstacles and challenges that may prevent retailers from implementing SRTs, he noted that the uncertainty of consumer acceptance to smart technologies is the biggest challenge. He stated that without the consumer acceptance to use smart retail technologies, the efforts to implement SRT would be unsuccessful and waste of resources.

Fifth: concerning the advantages of adopting SRTs in retailing, he noted that smart technologies can change all retail operations. It can increase the speed and flexibility of operations, help improve retailers' bottom line, inventory management and reduce order processing time. However, he believes that smart technologies would not be implemented in less than three to five years.

Sixth: with regards to his perception of the changes smart retail technologies may create, he noted that changes would be positive, furthermore confirms that with current growth of e-commerce on average $35 \%$ annually with respect to the steady situation in offline retailing that is currently declining due to COVID-19; He affirms that smart technologies become a necessary strategic response for offline retailers.

Seventh: with regards to his perception on consumers'willingness to accept and use SRTs, he noted that it mainly depends on consumers' age group, their education level and income.

Eighth: with regards to his acceptance to SRT adoption in the future, he confirmed his agreement and added that it can help retailers' offline retailers who must start to consider implementing smart retail technologies to catch up with ecommerce players and fulfilling consumers' demands for innovative and new shopping experiences.

\section{Case RE-04}

First: concerning the impact of COVIDCOVID-19 on the retail industry in Egypt, he claims that consumers shifted to online retailers to fulfill their shopping demands. He elaborated that the negative impact of COVID-19 on retail stores led to several decisions such as employees lay off and salary reduction. Moreover, the respondents stated that smart retail technology is a highly regarded solution for certain retailing sectors (e.g. cosmetics sector) in the current pandemic. He added it can maintain social distancing measures and decrease the human interaction. He, finally, noted that the pandemic changed consumers' attitudes, behaviors towards online shopping.

Second: concerning retailers' readiness to implement SRT, he noted that he believes that only brands have the essential capabilities to implement smart retail technologies now.

Third: concerning the smart technologies, he believes it will have the most impact if implemented within physical stores (offline), he believes that self checkout payment systems can be easy and simple for consumers in our region. . Furthermore, he added 
that smart retail technologies impact will differ from one retailer to another based on the retailers' products'offering and store formats.

Fourth: concerning the expected obstacles and challenges that may prevent retailers from implementing SRTs, he stated that 'financing investments, customers' acceptance, and dealing with employees' resistance are the main challenges to successfully adopt smart retail technologies".

Fifth: concerning the advantages of adopting SRTs in retailing, he noted that smart retail technologies can help retailers maximize the efficiencies of operation, optimize cost, and increase the company revenues.

Sixth: with regards to his perception of the changes smart retail technologies may create, he noted that both positive and negative changes will occur. As for the positive side, he believes that it can help retailers enhance consumer shopping experience, generate new revenue stream and save costs for retailers. As for the negative side, he stated that business executives would face high resistance from employees.

Seventh: with regards to his perception on consumer willingness to accept and use SRTs, he noted that it mainly depends on consumers' characteristics such as age, education, gender, and income. He believes that younger generations will be early adopters to accept and use smart technology.

Eighth: with regards to his acceptance to SRT adoption in the future, he confirmed his agreement and added that it would help retailers create a better customer experience, thus increase their sales and bottom line results.

\section{Case RE-05}

First: concerning the impact of COVID-19 on the retail industry in Egypt, he noted that with regards to online retailers, online sales have increased. He elaborated that the COVID-19 impacted the sales of offline retailers negatively. Furthermore, the respondent stated that he expects smart retail technologies to be very useful mainly for customers who have decided to apply social distancing and stay away from any risks caused by shopping in crowded stores (e.g. shopping malls). Finally, he noted that during pandemic outbreak, customers were panicking and had problems with communication.

Second: concerning retailers'readiness to implement SRT, he noted that he believes only well-known brands that have large amounts ofcash flow would be able to implement smart retail technologies.

Third: concerning the smart technologies, he believe it will have the most impact if implemented within physical stores (offline), he believes that the use of virtual mirrors automated checkout systems, and click and collect are very interesting technologies that can improve customers' shopping experience.

Fourth: concerning the expected obstacles and challenges that may prevent retailers 
from implementing smart retail technologies, he noted that the internet infrastructure, bureaucracy, and dealing with unskilled workers would be the biggest challenges.

Fifth: concerning the advantages of adopting SRTs in retailing, he noted that smart retail technologies can help retailers reduce costs, and ultimately increase the profits.

Sixth: with regards to his perception of the changes smart retail technologies may create, he noted that he believes that changes will be positive and negative. Smart technologies will help in reducing operating costs, increase profits, and allow retailers to decrease stores floor area and concentrate more on technological means.

Seventh: with regards to his perception on consumer willingness to accept and use SRTs, he noted that it mainly depends if consumers' will accept and use smart technology when introduced or will resist it and have concerns.

Eighth: with regards to his acceptance to SRT adoption in the future, he confirmed his agreement and added that adopting smart technologies can increase the productivity of the stores in terms of sales transactions; help customers checking for availability of products, support staff during shipments arrival.Consequently, improving service quality.

\section{Cross-Case Analysis and Discussion}

The cross-case analysis presents the similarities and differences between the 5 cases in light of the thematic map. Table (3) illustrates the 8 objectives and extracted themes from the the 5 cases analysed with respect to each objective.

\section{Table 5.13}

\section{Objectives and themes}

\begin{tabular}{c|c|c}
\hline objective & Theme & Case(s) \\
\hline The impact of COVID-19 & Impact on online retailers; & RE-01,RE-02,RE- \\
& Impact on offline retailers; & 03,RE-04,Re-05 \\
& Impact on SRT adoption ; & \\
\hline $\begin{array}{c}\text { Offline retailers readiness } \\
\text { to implement SRT }\end{array}$ & Modern retail sector. & RE-01,RE-02,RE- \\
\hline Smart retail technologies & Automated and self-checkout & RE-01,RE-03,RE- \\
(SRT) impact in physical & payment system, Virtual mirror, & $04, \mathrm{Re}-05$ \\
stores & Click and Collect. & RE-02 \\
\hline Obstacles and challenges & Real time in store promotion & RE-01,RE-02,RE- \\
that affect the adoption of & Customers' acceptance & $03, \mathrm{RE}-04$ \\
Smart Retail Technologies & & RE-01,RE-02,RE- \\
(SRT) & Financial challenges & $03, \mathrm{RE}-04$ \\
\cline { 1 - 2 } & &
\end{tabular}




\begin{tabular}{|c|c|c|}
\hline & $\begin{array}{l}\text { Employees' resistance } \\
\text { Internet infrastructure }\end{array}$ & $\begin{array}{l}\text { RE-04 } \\
\text { RE-05 }\end{array}$ \\
\hline $\begin{array}{c}\text { Advantages of smart } \\
\text { retail technologies (SRT) } \\
\text { adoption in retail sector }\end{array}$ & $\begin{array}{c}\text { Improved consumers' shopping } \\
\text { experience } \\
\text { Reduce operation and labor cost } \\
\text { Increase sales and revenue } \\
\text { Improve retail operation efficiency } \\
\text { Improve Inventory management } \\
\text { Help retail stores } \\
\text { compete with online shopping }\end{array}$ & $\begin{array}{c}\text { RE-01,RE-02,RE- } \\
\text { 03,RE-04,Re-05 } \\
\text { RE-01,RE-02, RE- } \\
\text { 04,Re-05 } \\
\text { RE-01,RE-02, RE- } \\
\text { 04,Re-05 } \\
\text { RE-01, RE-03,RE-04 } \\
\text { RE-01, RE-04 } \\
\text { RE-02, RE-03 }\end{array}$ \\
\hline $\begin{array}{c}\text { Retail experts perception } \\
\text { of post smart retail } \\
\text { technologies (SRT) } \\
\text { adoption results }\end{array}$ & $\begin{array}{l}\text { Positive perception } \\
\text { Negative perception }\end{array}$ & $\begin{array}{c}\text { RE-01,RE-02,RE- } \\
\text { 03,RE-04,Re-05 } \\
\text { RE-01 }\end{array}$ \\
\hline $\begin{array}{c}\text { Retail experts perception } \\
\text { of consumers' willingness } \\
\text { to adopt SRT }\end{array}$ & Positive perception & $\begin{array}{l}\text { RE-01,RE-02,RE- } \\
\text { 03,RE-04,Re-05 }\end{array}$ \\
\hline $\begin{array}{c}\text { Retail experts' acceptance } \\
\text { to adopt smart retail } \\
\text { technologies (SRT). }\end{array}$ & $\begin{array}{c}\text { Retail businesses acceptance } \\
\text { adopting SRTs to their advantage. }\end{array}$ & $\begin{array}{l}\text { RE-01,RE-02,RE- } \\
\text { 03,RE-04,Re-05 }\end{array}$ \\
\hline
\end{tabular}

\section{The Impact of COVID-19 on the Retail Industry in Egypt}

The emergence of COVID-19 global pandemic is one of the defining events of 2020 and its implications disrupted everything where huge challenges and uncertainties have overshadowed the retail growth for 2020 . Hence, it was necessary to discuss the impact of COVID-19 on the retail industry with the interviewees. Four primary themes have been extracted during the discussions with the interviewees: (1) Impact on online retailers; (2) Impact on offline retailers; (3) Impact on SRT adoption; (4) Impact on consumers. It is worth mentioning that all the respondents mentioned that online shopping grew while offline retailers' sales dropped.

According to The German-Arab Chamber of Industry and Commerce (GACIC) in Egypt, dependence on e-commerce has significantly increased in Egypt in which rising of Covid-19 and the physical distancing measures, encourage consumers to depend on online marketing sources for groceries, fresh food, hygiene products, clothes, medicine, electronics (AHK Egypt, 2020). Morover, 80\% of Egyptians made online purchases for food, health care products or clothes during the curfew from March until June to confront the coronavirus pandemic (Consumer Protection Agency, 2020). 
According to Fernandes (2020), retail sales fell by 20 percent over the same period and COVID-19 pandemic has disrupted everything where huge challenges and uncertainties have impacted the retail industry (Fernandes, 2020; Pantano et al., 2020). The respondents explained that Egyptian consumers' behavior changed, shoppers shifted to online retailers to fulfill their demands. Moreover, this pandemic accelerated the consumer adaptation to online shopping. They also indicated that smart retail technologies can be an inevitable solution during the current pandemic and they expect further adoption of smart technologies in the future.

Finally, all respondents explained that smart retail technologies can help offline stores to compete with online retailers, maintain the social distancing, reduce human interaction, and decrease risks caused by shopping at crowded stores.

For example: First: Concerning the impact of COVID-19 on the retail industry in Egypt respondent (RE-02) stated that with regards to online retailers "online sales have risen from last year". In his elaboration for the impact of COVID-19 on offline retailers he mentioned "During this outbreak, offline retailers sales have dropped, cash flow impacted negatively and forecasted profits for 2020 have fallen". Further, the respondent quoted in regards to the impact of COVID-19 on smart retail technologies adoption "COVID-19 will increase the adoption of smart technologies in stores and I believe offline retailer stores should deploy smart technologies to compete with online platforms". Finally he quoted in regards to the impact of COVID-19 on consumers "due to the current pandemic, consumers' adoption to use credit/debit cards or mobile wallets instead of cash in hand increased".

\section{Offline Retailers Readiness to Implement SRT}

Proceeding with the questions and topics, the interviewees expressed their thoughts in respect to offline retailers' readiness to implement smart retail technologies. The main trend was noted among the respondents that: in regards to the financial investments and human capital required only the multinational retailers in the modern retail sector and brands are likely to implement smart retail technologies.

The following quote is quite interesting "The well reputed retailers only will be able to successfully implement smart technologies with their financial and human capacity" (RE-02).

\section{Smart Retail Technologies (SRT) Impact in Physical Stores}

Regarding smart technologies, most of the respondents think automatic and selfcheckouts payment systems would have the biggest impact on consumers while shopping instores. Many of them indicated that the current checkout process is a serious source of disappointment for many customers because they have to wait in long queues before they can proceed to the cashier. One of the participants outlined the main advantages of automated and self-payment systems penetration in retailing in "simple, easy, speed up check out," RE-05 said. Inman and Nikolova (2017) pinpoint 
that several global retailers have begun to introduce the Scan and Go technology to reduce consumers wait time during check out process along with savings labor cost to the retailer. Kang et al. (2015) and Pantano and Priporas (2016) explained in their studies that consumers use smart technologies in shopping to avoid to avoid queues, carrying cash on hands and thus have a speedy and easy transactions

Also, respondents mentioned that virtual mirror, click and collect and real time in store promotions are very interesting technologies. Although most of them believe that smart retail technologies are important innovation and can improve customer shopping experience; however, interviewees were concerned from automated technologies system failures, and replacing humans totally, especially in developing countries; for example"Based on our type of customers, I believe in the Automated Checkout system since they will avoid standing in queues and waiting to pay in cash. The virtual mirror is a great idea especially in the current circumstances where we have to sanitize all products tried by different customers. Also click and collect is one of the very good applications that I expect to grow in Egypt" (RE-05).

\section{Obstacles and Challenges that Affect the Adoption of Smart Retail Technologies (SRT)}

One of the most important topics discussed with the interviewees were the obstacles and challenges that may prevent retailers from adopting Smart Retail Technologies. It was noticed that majority of the respondents (80\%) believe that customer acceptance and financial challenges are the main obstacles to adopt SRTs. For example RE-03 quoted "I believe the uncertainty of consumer acceptance to smart technologies is the biggest challenge without their acceptance; it will be unsuccessful and a waste of resources especially with the huge financial investments Smart Retail Technologies require" (RE-03). It is worth to mention that according to Alkemade and Suurs (2012), Evans (2011) and Pantano et al. (2013) studies, factors that most likely to intimidate retailers to employ smart technologies are uncertainty of consumer acceptance, massive financial investments required, and challenges in measuring returns on investments.

However, one of the interviewees mentioned employee resistance to change will cause uncertainty and consider being a significant factor in adopting SRTs. Additionally, other interviewee mentioned the internet infrastructure, software and dealing with incompetent technicians are major threat and obstacle to successfully adopt SRTs, i.e. "The software and internet infrastructure, bureaucracy and having to work with incompetent technicians are the worst obstacles we may face" (RE-05).

\section{Advantages of Smart Retail Technologies (SRT) Adoption in Retail Sector}

Retailers' benefits and advantages from smart retail technologies discussed with the respondents, six primary themes were extracted during the discussions with the interviewees: (1) Improved consumers' shopping experience; (2) Reduce operation and labor cost; (3) Increase sales and revenue; (4) Improve retail operation efficiency; 
(5) Improve Inventory management; (6) Help retail stores compete with online shopping.

All respondents mentioned that smart retail technologies can help retailer improve customers shopping experience in terms of faster shopping, enjoyable convenient personalized and easier. For example RE-02 quoted "Smart technology will transform retail businesses, it can facilitate customers shopping, make it faster and enjoyable. It can help stores to interact and engage with customer better; provide them with recommendations and good understanding what customers want". In addition, RE-04 quoted 'Smart retail technology will enhance customers' shopping experience especially younger generation and early adopters' consumers. I believe consumers look for more convenient and improved services like reducing shopping time ease of payment and credit, receiving deliveries faster, personalized offers etc." Fotiadis and Stylos (2017); Pantano and Priporas (2016) and Pantano and Viassone (2014) mentioned that retailers employ various novel and innovative (smart) technologies to enhance the consumers' shopping experience.

Furthermore, the majority of the interviewees $(80 \%)$ believe that Smart Retail Technology can help retailers reduce labor and operation cost and increase revenue. For example, RE-04 quoted "Smart retail technologies can help retailers maximize the efficiencies of operation, optimize cost and thus increase the company revenue". In addition, interviewees mentioned that retailers can benefit from SRTs in improving retail operation efficiency, improving inventory management, tracking goods across the supply chain, helping managers take better informed decisions in regard to goods pricing and preventing errors. According to Roy et al. (2017), Wünderlich et al. (2013), the implementation of Smart Retail Technology is expected to bring substantial benefits such as lower labor costs and increased efficiency for retailers.

Finally, two of the interviewees' highlighted that smart technology is necessary to physical stores to compete with the rise of online shopping; e.g. RE-02 quoted "Smart technology will help offline retailers to compete with online stores". Pantano and Timmermans (2014) mentioned that smart retail technology is considered to be a necessary strategic for offline retailers especially.

\section{Retail Experts' Perception of Post Smart Retail Technologies (SRT) Adoption Results}

Interview participants were asked to predict the post smart technologies adoption results. Most of the perceptions concentrated on the positive relevant consequences. Some representative excerpts are: "Definitely positive since the reduced costs would increase the profits of the company" (RE-05), "Certainly positive, because it will drive more revenue" (RE-02).

On the other hand, one of the interviewees expressed his concerns about the widespread use of smart technologies in retailing and the possible negative impact on 
particular job categories; such as, cashiers and stock clerks e.g. "Automation will eliminate jobs and eventually it may affect Egypt economy negatively" (RE-01).

This has been discussed in Priporas et al.'s (2017) study that expressed concerns about the possible negative consequences of the smart retailing on employment and job market since some of the technologies being Proposed (i.e. robots) may replace actual employees.

\section{Retail Experts' Perception of Consumers' Willingness to Adopt SRT}

Since consumer acceptance and the use of smart technology in retailing are the main challenges facing smart retail technooloy adoption, participants were asked about the perception in regards to consumer's willingness to accept and use smart retail technology. All of the interviewees believe that although it will be challenging at first, by time consumers will accept and use smart retail technologies in which age will be a significant factor e.g. "Consumers will adapt and get used to it by time" (RE-02, RE05), "It depends on consumers' age group, older generations will be a real challenge for retailers while Generation Y \& Z will accept and use smart technology and smart devices easily".(RE-01, RE-03, RE-04). According to Lee (2009), age is an important factor in the new digital culture that is why there are differences in different categories of consumers, (i.e., Generation Y, Generation Z) and in their expectations as consumers.

\section{Retail Experts' acceptance to Adopt Smart Retail Technologies (SRT)}

The last topic discussed during the semi-structured interviews with the retailer experts was whether to accept or not smart retail technology in the future. All of the participants were convinced that smart retail technology should be implemented to deal with COVID-19, improve customers shopping experience, help customers check for the availability of products, support staff during shipments arrival, improve quality of service, catch up with ecommerce players, deal with consumers' demands for innovative shopping, increase sales and revenue; e.g. "Definitely, smart retail technologies can help retailers deal with COVID-19 and improve customers shopping experience"(RE-01), "Definitely, offline retailers must consider implementing smart retail technologies to catch up with ecommerce players and dealing with consumers' demands for innovative shopping" (RE-03) and finally "Definitely, 100\% SRT will help retailers create a better customer experience and thus increase their sales and bottom line"(RE-04).

According to Greenhalgh et al. (2004), Pantano and Naccarato (2010), Weber and Kantamneni (2002) studies, the ability of retailers to build and defend their competitive market position depends on their willingness and capacity to use technology. 


\section{Conclusion}

COVID-19 pandemic has hit retail sector hardly, sales fell by 20 percent over the same period and huge challenges and uncertainties have impacted the industry and consumers' (Fernandes, 2020; Pantano et al., 2020). The findings provide an understanding on retail experts' insights in regards to interactions with smart technology in retail settings, perception, and expectations on the potential impact of smart technology on the industry and consumers in the future and exlpore the impact of COVID-19 pandemic on the retail industry.

First, all the interviewees agree that smart technology will spread and they hope that retailers will manage to adapt fast to this dynamic environment especially with the rise on online shopping and the emergence of COVID-19 global pandemic and its implications. Second, All interviewees highlighted that Egypt's modern retail sector (e.g. modern distribution areas, shopping malls and brands) had the financial and human resources required to successfully implement smart retail technologies. Third, most of the interviewees explained that the main challenges to smart retail technologies adoption are customer acceptance and financial challenges. Moreover, smart retail technologies adoption can face challenges such as employee resistance, internet availability, software, dealing with incompetent technicians and bureaucracy. Fourth, all interviewees pointed out that smart can retail technologies can enhance shoppers' experience on offline retail settings suggesting that smart retail technologies can deal with consumers' demands regarding the ease, speed, enjoyment and convenience of shopping transactions. Fifth, given the challenges offline retailers are facing from a host of online channels, all the interviewees agreed that smart technology is a promising route to establish competitive advantages. Sixth, Most of the interviewee's perceptions relevant to consequences of smart retail technologies adoption were positive. It was highlighted that smart retail technology should be implemented to deal with COVID-19, improve customers shopping experience, help customers checking for availability of products, support staff during shipments arrival, improving quality of service, to catch up with ecommerce players, dealing with consumers' demands for innovative shopping and increase sales and revenue. Finally, several interviewees noted their concerns in regards to the shift from the human to human interaction to human machines interaction. Morover interviewees highlighted their concern in the potential negative impact on job market and the number of employees due to SRTs adoption.

\section{References}

[1] "Egypt Demographics 2020 (Population, Age, Sex, Trends) - Worldometer", available at: https://www.worldometers.info/demographics/egyptdemographics/\#age-structure (accessed 29 January 2020)

[2] AHK Ägypten. (2020), "Corona Virus in Egypt", Available at: https://aegypten.ahk.de/en/corona-virus-in-egypt (Accessed 11 September 2020) 
[3] Ailawadi, K.L. and Farris, P.W. (2017), "Managing Multi- and Omni-Channel Distribution: Metrics and Research Directions", Journal of Retailing, available at:https://doi.org/10.1016/j.jretai.2016.12.003

[4] Alkemade, F. and Suurs, R.A.A. (2012), "Patterns of expectations for emerging sustainable technologies", Technological Forecasting and Social Change, available at:https://doi.org/10.1016/j.techfore.2011.08.014

[5] AT-Kearney. (2016), "Egypt ( Cautiously ) Back in Business"

[6] Ayres, L., Kavanaugh, K. and Knafl, K.A. (2003), "Within-case and across-case approaches to qualitative data analysis", Qualitative Health Research, available at:https://doi.org/10.1177/1049732303013006008

[7] Cpa.gov.eg. (2020), "Consumer Protection Agency", Available at: https://www.cpa.gov.eg/en-us/ (Accessed 11 September 2020)

[8] Dacko, S.G. (2017), "Enabling smart retail settings via mobile augmented reality shopping apps", Technological Forecasting and Social Change, available at:https://doi.org/10.1016/j.techfore.2016.09.032

[9] Evans, J.R. (2011), "Retailing in perspective: The past is a prologue to the future", International Review of Retail, Distribution and Consumer Research, available at:https://doi.org/10.1080/09593969.2011.537817

[10] Fagerstrøm, A., Eriksson, N. and Sigurdsson, V. (2020), "Investigating the impact of Internet of Things services from a smartphone app on grocery shopping", Journal of Retailing and Consumer Services, available at:https://doi.org/10.1016/j.jretconser.2019.101927

[11] Fernandes, N. (2020), "Economic Effects of Coronavirus Outbreak (COVID19) on the World Economy", SSRN Electronic Journal, available at:https://doi.org/10.2139/ssrn.3557504

[12] Firdausi, A. (2016), "Overview The Internet Of Things ( IOT ) System Security , Applications , Architecture And Business Models", No. September

[13] Fotiadis, A.K. and Stylos, N. (2017), "The effects of online social networking on retail consumer dynamics in the attractions industry: The case of 'E-da' theme park, Taiwan", Technological Forecasting and Social Change, available at:https://doi.org/10.1016/j.techfore.2016.06.033

[14] Gigli, M. and Koo, S. (2011), "Internet of Things: Services and Applications Categorization", Advances in Internet of Things, available at:https://doi.org/10.4236/ait.2011.12004

[15] Greenhalgh, T., Robert, G., Macfarlane, F., Bate, P. and Kyriakidou, O. (2004), "Diffusion of innovations in service organizations: Systematic review and recommendations", Milbank Quarterly, available at:https://doi.org/10.1111/j.0887-378X.2004.00325.x

[16] Gregory, J. (2015). The Internet of things: Revolutionizing the retail industry. Accenture Strategy. Retrieved November 10, 2019, from https://www.accenture.com/_acnmedia/Accenture/ConversionAssets/DotCom/Documents/Global/PDF/Dualpub_14/Accenture-TheInternet-Of-Things.pdf 
[17] Grewal, D., Roggeveen, A.L. and Nordfält, J. (2017), "The Future of Retailing”, Journal of Retailing, available at:https://doi.org/10.1016/j.jretai.2016.12.008

[18] Hoffman, D.L. and Novak, T.P. (2015), "Emergent Experience and the Connected Consumer in the Smart Home Assemblage and the Internet of Things", SSRN Electronic Journal, available at:https://doi.org/10.2139/ssrn.2648786

[19] Inman, J. and Nikolova, H. (2017), "Shopper-Facing Retail Technology", Journal of Retailing, available at:https://doi.org/10.2139/ssrn.2863022 T4 - An Adoption Decision Calculus Y3 - 06.09.2018 M4 - Citavi

[20] Kang, J.Y.M., Mun, J.M. and Johnson, K.K.P. (2015), “In-store mobile usage: Downloading and usage intention toward mobile location-based retail apps", Computers in Human Behavior, available at:https://doi.org/10.1016/j.chb.2015.01.012

[21] Kumar, M.S., Raut, D.R.D., Narwane, D.V.S. and Narkhede, D.B.E. (2020), "Applications of industry 4.0 to overcome the COVID-19 operational challenges", Diabetes and Metabolic Syndrome: Clinical Research and Reviews, available at:https://doi.org/10.1016/j.dsx.2020.07.010

[22] Lee, I. and Lee, K. (2015), "The Internet of Things (IoT): Applications, investments, and challenges for enterprises", Business Horizons, "Kelley School of Business, Indiana University", Vol. 58 No. 4, pp. 431-440

[23] Lee, S. (2009), "Mobile internet services from consumers' perspectives", International Journal of Human-Computer Interaction, available at:https://doi.org/10.1080/10447310902865008

[24] Manyika, J., Chui, M., Bisson, P., Woetzel, J., Dobbs, R., Bughin, J. and Aharon, D. (2015), "The Internet of Things: Mapping the value beyond the hype", McKinsey Global Institute

[25] Miorandi, D., Sicari, S., De Pellegrini, F. and Chlamtac, I. (2012), "Internet of things: Vision, applications and research challenges", Ad Hoc Networks, available at:https://doi.org/10.1016/j.adhoc.2012.02.016

[26] Morse, J.M. (1995), "The significance of saturation", Qualitative Health Research, available at:https://doi.org/10.1177/104973239500500201

[27] Pantano, E. and Naccarato, G. (2010), "Entertainment in retailing: The influences of advanced technologies", Journal of Retailing and Consumer Services, available at:https://doi.org/10.1016/j.jretconser.2010.03.010

[28] Pantano, E. and Priporas, C.V. (2016), "The effect of mobile retailing on consumers' purchasing experiences: A dynamic perspective", Computers in Human Behavior, available at:https://doi.org/10.1016/j.chb.2016.03.071

[29] Pantano, E. and Timmermans, H. (2014), "What is Smart for Retailing?", Procedia Environmental Sciences, available at:https://doi.org/10.1016/j.proenv.2014.11.010

[30] Pantano, E. and Viassone, M. (2014), "Demand pull and technology push perspective in technology-based innovations for the points of sale: The 
retailers evaluation", Journal of Retailing and Consumer Services, available at:https://doi.org/10.1016/j.jretconser.2013.06.007

[31] Pantano, E., Iazzolino, G. and Migliano, G. (2013), "Obsolescence risk in advanced technologies for retailing: A management perspective", Journal of Retailing and Consumer Services, available at:https://doi.org/10.1016/j.jretconser.2013.01.002

[32] Pantano, E., Pizzi, G., Scarpi, D. and Dennis, C. (2020), "Competing during a pandemic? Retailers' ups and downs during the COVID-19 outbreak", Journal of Business Research, available at:https://doi.org/10.1016/j.jbusres.2020.05.036

[33] Pantano, E., Rese, A. and Baier, D. (2017), "Enhancing the online decisionmaking process by using augmented reality: A two country comparison of youth markets", Journal of Retailing and Consumer Services, available at:https://doi.org/10.1016/j.jretconser.2017.05.011

[34] Parker, G., Pickard, J., Cookson, C. and Pickford, J. (2020), "UK to launch business rescue package to fight coronavirus fallout", Financial Times, , Retrieved 5 September 2020 from https://www.ft.com/content/30931d906821-11ea-800d-da70cff6e4d3

[35] Patton, M.. (1990), "Qualitative evaluation and research methods (2nd ed.), Newbury Park, CA":, Research in Nursing \& Health, available at:https://doi.org/10.1002/nur.4770140111

[36] Priporas, C.V., Stylos, N. and Fotiadis, A.K. (2017), “Generation Z consumers' expectations of interactions in smart retailing: A future agenda", Computers in Human Behavior, available at:https://doi.org/10.1016/j.chb.2017.01.058

[37] Priporas, C.V., Stylos, N. and Fotiadis, A.K. (2017), "Generation Z consumers' expectations of interactions in smart retailing: A future agenda", Computers in Human Behavior, available at:https://doi.org/10.1016/j.chb.2017.01.058

[38] Renko, S. and Druzijanic, M. (2014), "Perceived usefulness of innovative technology in retailing: Consumers' and retailers' point of view", Journal of Retailing and Consumer Services, available at:https://doi.org/10.1016/j.jretconser.2014.02.015

[39] Roy, S.K., Balaji, M.S., Quazi, A. and Quaddus, M. (2018), "Predictors of customer acceptance of and resistance to smart technologies in the retail sector", Journal of Retailing and Consumer Services, available at:https://doi.org/10.1016/j.jretconser.2018.02.005

[40] Roy, S.K., Balaji, M.S., Sadeque, S., Nguyen, B. and Melewar, T.C. (2017), "Constituents and consequences of smart customer experience in retailing", Technological Forecasting and Social Change, Elsevier Inc., Vol. 124 No. 2017, pp. 257-270

[41] Vaishya, R., Javaid, M., Khan, I.H., and Haleem, A. (2020), "Artificial Intelligence (AI) applications for COVID-19 pandemic", Diabetes and Metabolic Syndrome: Clinical Research and Reviews, available at:https://doi.org/10.1016/j.dsx.2020.04.012 
[42] Vasileiou, K., Barnett, J., Thorpe, S. and Young, T. (2018), “Characterising and justifying sample size sufficiency in interview-based studies: Systematic analysis of qualitative health research over a 15-year period", BMC Medical Research Methodology, available at:https://doi.org/10.1186/s12874-0180594-7

[43] Verhoef, P.C., Kannan, P.K. and Inman, J.J. (2015), "From Multi-Channel Retailing to Omni-Channel Retailing. Introduction to the Special Issue on Multi-Channel Retailing.", Journal of Retailing, available at:https://doi.org/10.1016/j.jretai.2015.02.005

[44] Weber, M.M. and Kantamneni, S.P. (2002), "POS and EDI in retailing: An examination of underlying benefits and barriers", Supply Chain Management, available at:https://doi.org/10.1108/13598540210447755

[45] Whitmore, A., Agarwal, A. and Da Xu, L. (2015), "The Internet of Things-A survey of topics and trends", Information Systems Frontiers, available at:https://doi.org/10.1007/s10796-014-9489-2

[46] Willems, K., Smolders, A., Brengman, M., Luyten, K. and Schöning, J. (2017), "The path-to-purchase is paved with digital opportunities: An inventory of shopper-oriented retail technologies", Technological Forecasting and Social Change, available at:https://doi.org/10.1016/j.techfore.2016.10.066

[47] World Bank. (2020), "The Global Economic Outlook during the COVID-19 Pandemic: A Changed World", The World Bank, available at: https://www.worldbank.org/en/news/feature/2020/06/08/the-globaleconomic-outlook-during-the-covid-19-pandemic-a-changed-world (accessed 5 September 2020)

[48] World Bank. (2020), "The Global Economic Outlook During the COVID-19 Pandemic: A Changed World", The World Bank, available at: https://www.worldbank.org/en/news/feature/2020/06/08/the-globaleconomic-outlook-during-the-COVID-19-pandemic-a-changed-world (accessed 5 September 2020)

[49] Wünderlich, N. V., Wangenheim, F. V. and Bitner, M.J. (2013), "High Tech and High Touch: A Framework for Understanding User Attitudes and Behaviors Related to Smart Interactive Services", Journal of Service Research, available at:https://doi.org/10.1177/1094670512448413

[50] Zhitomirsky-Geffet, M. and Blau, M. (2016), "Cross-generational analysis of predictive factors of addictive behavior in smartphone usage", Computers in Human Behavior, available at:https://doi.org/10.1016/j.chb.2016.07.061

\section{Appendix A: interview with retail experts}

Before we start please indicate;

Your Name:

Company/Organization:

Size of Your Organisation: 
Location:

Position at your organization:

How is the current COVID-19 pandemic affecting the retail industry in Egypt?

To what extent SRTs could help the retail industry during the current pandemic crisis?

Which retailers have the "capabilities necessary for successful Smart Retail Technologies implementation?

Which smart retail technologies will have the biggest impact if implemented within retail stores? Why?

What are the obstacles and challenges that may prevent retailers from adopting Smart Retail Technologies?

What are the changes and expected benefits to take place if retailers adopt smart retail technologies?

What is your perception regarding the changes smart retail technologies may create?

Do you think the consumer will accept using Smart Retail Technologies? Why?

Are you considering/ accepting adopting Smart Retail Technologies? Why? 